\title{
Effect of Labor Camera on the Duration of the Second Stage Labor in Primipara
}

\author{
Yetti Purnama, Kurnia Dewiani, Linda Yusanti \\ Department of Midwifery, Faculty of Mathematics and Natural Sciences, \\ Universitas Bengkulu, Bengkulu, Indonesia
}

\begin{abstract}
Fear and anxiety due to severe labor pains could also lead to prolonged labor. The efforts made to accelerate the second stage labor process are by providing emotional support with the support of a labor camera. The mother is allowed to observe the development state of her baby's head through video on a tablet or laptop screen. Furthermore, the mother's emotional level becomes more provoked and motivated to strain the labor process faster. This study aims to determine the effect of the labor cameras on the second state duration in primiparous. The design of this study was a posttest-only control group design experiment with a total sample of 30 primiparous of the second stage at independent midwife practice in Bengkulu city in November-December 2020. Each group consisted of 15 for treatment (with labor cameras) and 15 for control (without labor cameras)-the assessment of the labor duration by counting the labor time in seconds during the second state. The statistical results using the t test and chi-square test analysis showed that the intervention group's labor duration (1,393.3 seconds) was shorter than the control group's (2,340.6 seconds). The mean difference in the delivery time was 947.3 seconds or 15.7 minutes faster in the intervention group than in the control group. In conclusion, using a labor camera on the labor duration of the second stage in primiparous mothers is an effect of using a labor camera.
\end{abstract}

Keywords: Labor camera, labor duration, primipara

\section{Pengaruh Kamera Persalinan terhadap Durasi Persalinan Kala II pada Primipara}

\begin{abstract}
Abstrak
Rasa takut dan cemas akibat nyeri persalinan yang berat juga dapat menyebabkan partus lama. Salah satu upaya yang dilakukan untuk mempercepat proses kala II persalinan adalah memberikan dukungan emosional dengan bantuan kamera persalinan. Ibu diberi kesempatan untuk melihat perkembangan pengeluaran kepala bayinya melalui video pada layar tablet atau laptop sehingga tingkat emosional ibu menjadi lebih terbangun dan termotivasi untuk mempercepat proses persalinan. Penelitian ini bertujuan mengetahui pengaruh kamera persalinan terhadap durasi persalinan kala II pada primipara. Desain penelitian adalah eksperimen posttest-only control group design dengan jumlah sampel 30 primipara kala II di bidan praktik mandiri Kota Bengkulu pada November-Desember 2020. Tiap-tiap kelompok berjumlah 15 untuk kelompok perlakuan (menggunakan kamera persalinan) dan 15 untuk kontrol (tidak menggunakan kamera persalinan). Penilaian durasi persalinan dengan menghitung detik selama kala II berlangsung. Pengujian statistik menggunakan analisis uji t dan uji chi-square menunjukkan bahwa durasi persalinan kelompok perlakuan (1.393,3 detik) lebih singkat daripada kelompok kontrol (2.340,6 detik). Selisih perbedaan waktu persalinan rerata selama 947,3 detik atau 15,7 menit lebih cepat pada kelompok intervensi dibanding dengan kelompok kontrol. Simpulan, terdapat pengaruh penggunaan kamera persalinan terhadap durasi persalinan kala II pada ibu primipara.
\end{abstract}

Kata kunci: Kamera persalinan, lama persalinan, primipara

Received: 3 December 2020; Revised: 5 August 2021; Accepted: 5 August 2021; Published: 31 August 2021

Correspondence: Yetti Purnama, S.S.T., M.Keb. Department of Midwifery, Faculty of Mathematics and Natural Sciences, Universitas Bengkulu. Jln. Indragiri No. 4, Bengkulu 38225, Bengkulu, Indonesia. E-mail: yettipurnama123@gmail.com 


\section{Introduction}

Labor is a natural process; the World Health Organization estimates that around $70-80 \%$ of pregnant women have a low risk from labor to birth. The progress of labor is influenced by the 5 P's, namely passage, passenger (fetus or baby), power (strength of uterus contraction), psyche (psychological condition), and position if any of the components change, the outcome of labor can be adversely affected. Prolonged labor or dystocia could increase maternal and neonatal mortality and morbidity. The failure of the labor progress is caused by mechanical problems with the mismatch between the size of the presenting part of the fetus and the mother's pelvis, malpresentation, labor in the posterior occipital position, and ineffective uterus contraction. ${ }^{1-4}$

Fear and anxiety due to severe labor pains could also lead to prolonged labor because stimulation of the sympathetic nervous system trigger increased catecholamine secretion. Further, it leads to increase levels of the hormone epinephrine, which results in weak uterus contraction in case uterus contraction does not align with the cervical opening. ${ }^{1,5}$ The mothers who experience anxiety during childbirth, 30\% encounter fear during childbirth. The traumatic experience of childbirth causes a more extended time interval at subsequent deliveries and increases the risk for cesarean section. ${ }^{6,7}$ The results of a case-control study by Sydsjo et al. ${ }^{6}$ in Southeast Sweden in 2001-2007 on 23,000 samples showed the mothers who experienced fear during childbirth were 5.2 times at risk for cesarean section, and severe fear increased labor duration by 40 minutes in the active phase $(\mathrm{p}<0.001)$.

The efforts are made to accelerate the second stage labor process by providing emotional support. The action given is with the support of a childbirth mirror where the mother can see the development of her baby's expenditure. Furthermore, the emotional level of the mother's emotional level becomes more provoked and motivated to strain and the labor process faster. However, the labor mirrors have limited visibility and are unsupported to see closely related to the delivery process and inflexibility in placement due to the large size of the mirror. ${ }^{8-10}$

The labor mirror was developed into a video directly seen and had the advantage of a wider, clearer, and closer saw range through the monitor screen. In addition, there is a zoom-in feature and more flexibility in placing cameras and monitors when considering the dimension factor and the purposes of analysis of labor in the event of a pathological condition. Furthermore, the mothers who intend to the moment documentation can be recorded using live video by using the labor camera during the labor process. The physiological effect is when the baby's head begins to provide encouragement and motivation. The video is a method to reduce pain in an active way and decrease the second stage of labor. ${ }^{9,11-14}$

The preliminary results of this study conducted at the independent midwife practice of Bengkulu city have not implemented a labor camera yet to assist the acceleration of the second stage of labor. For this reason, midwives must use a labor camera that can record the birth process directly and be seen through a monitor/ screen on a television or other software to provide motivation and accelerate the second stage of the labor process. Therefore, this study was conducted to determine the effect of using a labor camera on the duration of second-stage labor in primiparous mothers.

\section{Methods}

The study design used an experiment with a posttest-only control group design and the sample selection using an accidental sampling technique. The study group consisted of the treatment group (with labor camera) and the control group (without labor camera) and was randomized with random permuted blocks. Labor camera was a tool designed to assist childbirth using a portable camera and motion sensor with a microcontroller. Furthermore, it was displayed on the monitor to assist the mother in seeing the delivery process.

The study was evaluated two variables; the independent variable was the labor camera used to monitor the delivery process, the dependent variable was the length of the second stage of labor, the time used from complete dilatation to the baby was born.

The research has been implemented at ten independent midwife practices in Bengkulu city from November to December 2020 and was carried out sequentially with other research teams researching appropriate technology for labor cameras. During the study period, 30 secondstage primiparous, each group amounting to 15 
for treatment (with labor camera) and control (without labor camera/conventional). The subject criteria were second stage primiparous labor, single pregnancy, age 20-35 years, primipara opening $10 \mathrm{~cm}$ (complete), head presentation of posterior fontanel in front, 37-42 weeks of gestation, intact amniotic fluid. In addition, they also have to have good uterus contraction, regular rhythm, frequency $3 \times$ deep 10 minutes, did not get labor induction, and interpreted fetal weight $>2,500$ g to $<4,000$ g. Next, exclusion criteria: head and pelvis disproportion; hemoglobin $<11$ $\mathrm{g} / \mathrm{dL}$; mothers with body mass index $<18.5$ or $\geq 30$; pregnancies with complications such as pre-eclampsia, eclampsia, antepartum bleeding, and contraindications for vaginal delivery; and without companions during the labor. Finally, the drop-out criteria are mothers who could not continue vaginal labor, precipitated labor, prolonged labor, assessment of the labor duration using a stopwatch with a count of seconds.

The assessment of labor duration was performed by using a digital stopwatch with a count of seconds. Further, the analysis was by bivariate analysis test. First, the characteristic data were compared using the chi-square test. Second, the data normality test was evaluated using the Shapiro-Wilk test. Finally, analysis of the time differences in labor duration in the control and treatment groups was analyzed using the $t$ test.

The Health Research Ethics Committee of the Faculty of Medicine and Health Sciences of the Universitas Bengkulu has approved this research, with the ethics committee approval number: 324/ UN30.14.9/LT/2O2O.

\section{Results}

The research subject is 30 respondents and divided into two groups. Each group is 30 respondents, group A, namely the treatment group with the labor camera and group B without the labor camera (conventional).

Table 1 shows that the subject's characteristics are followed by the inclusion and exclusion criteria for the study determined. The sample was 30 , divided into 15 respondents in the intervention group and 15 in the control group. All respondents are recorded on education level, time of rupture of membranes, and weight of newborns.

The results of the data normality test with Shapiro-Wilk data were not normally distributed with a significance value of $p>0.05$, generally distributed in the two groups, namely, intervention and control. Thus, the purposes of the analysis used parametric statistics, namely the independent $t$ test.

Table 2 shows that the control group's average labor duration is $1,393.3$ seconds shorter than the control group's 2,340.6 seconds. The time difference in the labor duration time is 947.3 seconds or 15.7 minutes faster in the intervention group than in the control group. Based on the results of statistical testing using an unpaired $t$ test, the probability value obtained is smaller than the predetermined significance level $(<0.05)$. The

Table 1 Characteristics of the Research Subjects

\begin{tabular}{|c|c|c|c|}
\hline \multirow[b]{2}{*}{ Characteristics } & \multicolumn{2}{|c|}{ Category } & \multirow[b]{2}{*}{ p Value } \\
\hline & $\begin{array}{l}\text { Treatment } \\
(\mathbf{n}=15)\end{array}$ & $\begin{array}{c}\text { Control } \\
(n=15)\end{array}$ & \\
\hline Education level & & & 0.642 \\
\hline Low & 2 & 1 & \\
\hline Middle & 10 & 9 & \\
\hline High & 3 & 5 & \\
\hline Time of rupture of membranes & & & 0.000 \\
\hline Opening 7-8 cm & 6 & 6 & \\
\hline Opening 9-10 cm & 9 & 9 & \\
\hline Weight of newborn (gram) & & & 0.593 \\
\hline $2,500-2,900$ & 3 & 3 & \\
\hline $3,000-3,500$ & 12 & 11 & \\
\hline $3,600-4,000$ & $\mathrm{O}$ & 1 & \\
\hline
\end{tabular}


Table 2 Comparison of the Labor Duration in the Two Categories

\begin{tabular}{lcclc}
\hline \multirow{2}{*}{$\begin{array}{l}\text { Second Stage } \\
\text { of Labor }\end{array}$} & \multicolumn{2}{c}{ Category } & Time Difference & p Value $^{*}$ \\
\cline { 2 - 3 } & $\begin{array}{c}\text { Intervention } \\
(\mathbf{n = 1 5})\end{array}$ & $\begin{array}{c}\text { Control } \\
(\mathbf{n = 1 5 )}\end{array}$ & & \\
\hline Mean & $1,393.3$ & $2,340.6$ & 947.3 seconds or & 0.000 \\
SD & 263.7 & 334.53 & 15.7 minutes & \\
\hline
\end{tabular}

Note: "t test

results indicate a significant effect of the labor duration in the treatment group is shorter than the control group.

\section{Discussion}

The characteristics of the two groups observed are education, time of rupture of membranes, and the bodyweight of the newborn. The first characteristic is education. Most of the respondents' education is in middle-level education, both in the intervention and control groups. A person's level of education is very significant in health conditions and affects more to a person's perception of receiving better information. The participant with a high-level education will easily accept the information provided. Information about childbirth can improve the experience of mothers during childbirth so that mothers will concentrate more, and their motoric activities are focused on being able to control pain due to uterus contractions, fear, and anxiety to deal with childbirth. Labor pain, fear, and anxiety affect psychological responses that impact the progress of labor..$^{1,15-17}$

The second characteristic of the study subjects is the time of the rupture of membranes. The characteristics of the amniotic fluid in the treatment group and the control group are mostly in the spontaneous rupture of membranes and the time of the rupture of the membranes at $7-8 \mathrm{~cm}$ opening. The amniotic membrane is composed of an amniotic membrane. The chorion covers the fetal surface of the placenta and forms a sac that contains the fetus and supports the fetus and amniotic fluid. The amniotic membrane produces amniotic fluid. The membranes should rupture spontaneously at the onset of labor or remain intact throughout the active labor process until the doctor or midwife decides to break the membranes or until the baby is born. Rupture of the membranes can cause the fetal head to pass through the pelvis and shorten labor duration.
When the membranes rupture, the production and release of prostaglandins and oxytocin increase so that contractions become stronger and cervical opening is faster. Pressure from the intact membrane contributes to the ripening, thinning, and opening of the cervix..$^{1-3,18}$

The characteristics of the birth weight of the babies in both groups are in the range of $3,000-3,499 \mathrm{~g}$. Baby weight is related to head circumference and shoulder width. Birth weight affects the labor duration about the size of the pelvis, which is considered sufficient to deliver a vaginal size to a normal-sized baby. The labor duration and the need for cesarean section are related to fetal weight. The number of cesarean sections doubles from $4 \%$ in infants weighing $3,500-3,999 \mathrm{~g}$ to $8 \%$ when the fetal weight is 4,000-4,999 g. ${ }^{1-4}$

Research on the second stage duration of labor shows a significant difference between the treatment group and the control group. The results supported the analysis, which could be seen from the stage of labor at the second stage. Statistical analysis also shows a significant difference between the treatment group and the control group.

The study's statistical results on the time difference in the labor duration on the second stage with and without the labor camera group show a significant difference in the two groups. In labor with the camera group, the statistical results using an independent $t$ test show a time difference in the second stage of labor between the group with and without labor camera $(\mathrm{p}<0.05)$ as shown 1,393.3 and 2,340.6 seconds. The time difference in the mean duration of delivery time is 947.3 seconds or 15.7 minutes faster in the intervention group than in the control group. This situation indicates that implementing a labor camera motivates mothers to deliver when straining and accelerate the second stage of the labor in primiparous.

The results have shown a corresponding with 
Doyle et al., ${ }^{9}$ which has been done between 2013 to 2014 in intra-natal care service centers in the USA. Five hundred respondents were researched with postpartum mothers aged 18-49 years. The results have described the frequency of using mirrors in childbirth to increase the focus on accepting and accelerating the process of expelling the baby of $53 \%$, and $58 \%$ stated they use mirrors during the process of expelling the baby was a positive experience for them.

Becerra-Maya et al.'s ${ }^{18}$ research results with a descriptive cross-sectional research method are conducted at the Universitario Fundación Alcorcón Hospital (Madrid, Spain). The data are collected using a 14 item scale based on a semantic differential technique developed from a pilot study with 92 subjects. The results of the study indicate $73 \%$ ( $95 \% \mathrm{CI}=62.7$ and 84.4 ) of the use of mirrors during the labor process support efforts to give birth and facilitate labor effectiveness. Mirrors are used to guide labor, observe the process of their baby's birth, and enhance the labor experience.

Palompon et al.'s ${ }^{19}$ research in the Philippines examined the effectiveness of mirrors in accelerating the second stage of childbirth in primiparous with a post-test design research method with 20 primiparous respondents. The results showed that the intervention group obtained an average of 6.77 with a mean difference of $12.15 \quad(\mathrm{SD}=5.24)$. It shows a significant difference in accelerating the duration of secondstage labor.

The results of Novianti and Rokhamah's $\mathrm{s}^{20}$ research at Paru Batu Hospital, Indonesia, have shown a comparison between the two treatment and control groups in primiparous. The results showed that the mirror is an effective method because it can accelerate the second stage of labor in primigravida mothers with an average time of 13 minutes. For those who do not use a mirror, the average time required is 25 minutes.

Fear and anxiety due to severe labor pains caused prolonged labor because stimulation of the sympathetic nervous system stimulates increased catecholamine secretion, leading to increased levels of the hormone epinephrine. The results in weak uterus contraction indicate the contraction is not in line with the cervical opening. ${ }^{1,2,20}$ The mother who has labor anxiety will increase the experience of fear by $30 \%$ during childbirth. The traumatic experience of childbirth causes a more extended time interval at subsequent deliveries and increases the risk for cesarean section. The results of a case-control study by Sydsjo et al. ${ }^{6}$ in Southeast Sweden in 2001-2007 with 23,000 samples showed the mothers who experienced fear during childbirth were 5.2 times at risk for cesarean section, and severe fear increased labor duration by 40 minutes in the active phase $(\mathrm{p}<0.001)$.

The labor mirror was developed into a video directly seen and had the advantage of a broader, clearer, and closer range through the monitor screen. In addition, there is a zoom-in feature and more flexibility in placing cameras and monitors when considering the dimension factor and the purposes of analysis of labor in the event of a pathological condition. ${ }^{22,23}$ Furthermore, the mothers who intend to the moment documentation can be recorded using live video by using the labor camera during the labor process. The physiological effect is when the baby's head begins to provide encouragement and motivation. The video is a method to reduce pain in an active way and decrease the second stage of labor.

Many factors influence the future works, the duration of delivery. Therefore, it is necessary to do further research examining other variables that could affect the duration of labor, such as the variable anxiety factor.

\section{Conclusion}

This study concluded that using a labor camera on the labor duration of the second stage in primiparous mothers is an effect of using a labor camera.

\section{Conflict of Interest}

All authors stated that there was no conflict of interest in this article.

\section{Acknowledgments}

We sincerely thank the Dean of the Faculty of Mathematicsand NaturalSciences, theUniversitas Bengkulu, and LPPM Universitas Bengkulu, who has helped fund the implementation of this research with contract number 2048/UN30.12/ $\mathrm{HK} / 2020$. We also would like to those who have assisted in the design and production of the labor camera. Finally, thanks to the research team who collaborated on this research. 


\section{References}

1. Lowdermilk DL, Perry SE, Chasion MC. Keperawatan maternitas. $8^{\text {th }}$ Edition. St. Louis: Mosby; 2013.

2. Lockhart A, Saputra L. Asuhan kebidanan masa persalinan fisiologis dan patologis. Tangerang Selatan: Binarupa Aksara; 2014.

3. Nystedt A, Hildingsson I. Diverse definitions of prolonged labour and its consequences with sometimes subsequent inappropriate treatment. BMC Pregnancy Childbirth. 2014;14:233.

4. Murray ML, Huelsmann GM, Ananda W. Persalinan \& melahirkan: praktik berbasis bukti. Jakarta: EGC; 2013.

5. Gizzo S, Di Gangi S, Noventa M, Bacile V, Zambon A, Nardelli GB. Women's choice of positions during labour: return to the past or a modern way to give birth? A cohort study in Italy. Biomed Res Int. 2014;2014:638093.

6. Sydsjö G, Angerbjörn L, Palmquist S, Bladh M, Sydsjö A, Josefsson A. Secondary fear of childbirth prolongs the time to subsequent delivery. Acta Obstet Gynecol Scand. 2013;92(2):210-4.

7. Lawrence A, Lewis L, Hofmery GJ, Style C. Maternal positions and mobility during first stage labour. Cochrane Database Syst Rev. 2013;(10):CDoo3934.

8. Suzuki S. Clinical significance of precipitous labor. J Clin Med Res. 2015;7(3):150-3.

9. Doyle J, Lyzen A, McCarrol M, Frantz K, Kenny T, Gruenigen V. Maximizing maternal birth experience through the use of labor mirror. J Preg Child Health. 2016;3(1):218.

10. Ali Andre J. Sistem security webcam dengan menggunakan Microsoft Visual Basic (6.0). Rabit. 2016;1(2):48-60.

11. Purnama Y, Dewiani K, Yusanti L. Cermin persalinan dalam mempercepat proses kala II persalinan [Internet]. Yogyakarta: Universitas Alma Ata Yogyakarta; 2019 July [cited 2021 January 19]. Available from: https://fikes.almaata.ac.id/wp-content/ uploads/2019/o7/Yetti-Purnama.fix_.pdf.

12. Ahmed S, Khan A, Babar I. Monitoring detection and security maintenance using WMS-webcam mobile surveillance. In: Anwar M, Owais SM, Suhail A, Alvi QH, Hussain MY, Hussain MY, editors. Proceedings Third International Conference on Emerging Technologies 2007 (ICET 2007); 2007
November 12-13; Islamabad, Pakistan. Piscataway, New Jersey, USA: Institute of Electrical and Electronics Engineers; 2007 [cited 2021 January 19]. p. 58-61. Available from: https://doi.org/10.1109/ ICET.2007.4516316.

13. Robinson D. Practical systems for live streaming. In: Pathan M, Sitaraman RK, Robinson D, editors. Advanced content delivery, streaming, and cloud services. Hoboken, New Jersey, USA: Wiley-IEEE Press; 2014. p. 51-70.

14. Shagholi A, Charmi M, Rakhshan H. The effect of the distance from the webcam in heart rate estimation from face video images. In: $20152^{\text {nd }}$ International Conference on Pattern Recognition and Image Analysis (IPRIA 2015); 2015 March 11-12; Rasht, Iran. Piscataway, New Jersey, USA: Institute of Electrical and Electronics Engineers; 2015 [cited 2021 January 19]. Available from: https://doi.org/10.1109/PRIA.2015.7161622.

15. Ebrahimzadeh S, Golmakani N, Kabirian M, Shakeri MT. Study of correlation between maternal fatigue and uterine contraction pattern in the active phase of labour. J Clin Nurs. 2012;21(11-12):1563-9.

16. Charles C. Labour and normal birth. In: Chapman V, Charles C, editors. The midwife's labour and birth handbook. $4^{\text {th }}$ Edition. Hoboken, New Jersey, USA: John Wiley \& Sons; 2018. p. 1-48.

17. Chapman V. Slow progress in labour. In: Chapman V, Charles C, editors. The midwife's labour and birth handbook. $4^{\text {th }}$ Edition. Hoboken, New Jersey, USA: John Wiley \& Sons; 2018. p. 171-88.

18. Becerra-Maya EJ, LapuenteJambrina G, AlonsoOrtega VM. Use of the mirror in second stage of labor: evaluation by means of semantic differential. Index Enferm. 2011;20(1-2):46-50.

19. Palompon D, Bono DM, Pastrano M, Ladonga PM, Ramirez A, Laureano $\mathrm{H}$, et al. Visual biofeedback: adjunct mirror intervention during stage two labor among primiparous women. Asian J Health. 2011;1(1):204-16.

20. Novianti A, Rokhamah. Kajian metode persalinan normal dengan bantuan cermin pada persalinan kala II ibu primigravida di Rumah Sakit Paru Batu. Biomed Sci. 2015;3(2):39-46.

21. Fitriani, Mose JC, Herman H. Difference 
duration of labor at BC-MK15 birth chair with conventional bed in multiparous. GMHC. 2018;6(2):105-12.

22. Sheng Q, Liu T, Hou W, Wang G. The research on touch gestures interaction design for personal portable computer. In: $\mathrm{Zu} \mathrm{Q}$, $\mathrm{Hu}$ B, editors. Human centered computing: Third International Conference, HCC 2017, Kazan, Russia, August 7-9, 2017. Revised Selected Papers. Basel, Switzerland: Springer International Publishing; 2018. p. 527-37.

23. Zhang Q, Xu GQ, Wang M, Zhou Y, Feng
W. Webcam based non-contact real-time monitoring for the physiological parameters of drivers. In: $4^{\text {th }}$ Annual IEEE International Conference on Cyber Technology in Automation, Control and Intelligent Systems (IEEE-CYBER 2014); 2014 June 4-7; Hong Kong, China. Piscataway, New Jersey, USA: Institute of Electrical and Electronics Engineers; 2014 [cited 2021 January 19]. p. 648-52. Available from: https://doi. org/10.1109/CYBER.2014.6917541. 